OPEN ACCESS

Edited by:

Rima Menassa,

Agriculture and Agri-Food Canada,

London

Reviewed by:

Ann Meyers,

University of Cape Town, South Africa

Johannes Felix Buyel,

Fraunhofer Institute for Molecular Biology and Applied Ecology,

Germany

*Correspondence: Jianguo Su

sujianguo@mail.hzau.edu.cn Jihong Liu Clarke

jihong.liu-clarke@nibio.no

Specialty section: This article was submitted to

Plant Biotechnology,

a section of the journal

Frontiers in Plant Science

Received: 01 June 2021

Accepted: 07 July 2021

Published: 12 August 2021

Citation:

Su $H$, Yakovlev $I A$, van Eerde $A$,

Su J and Clarke JL (2021) Plant-

Produced Vaccines: Future Applications in Aquaculture.

Front. Plant Sci. 12:718775.

doi: 10.3389/fp/s.2021.718775

\section{Plant-Produced Vaccines: Future Applications in Aquaculture}

\author{
Hang Su ${ }^{1,2}$, Igor A. Yakovlev ${ }^{1}$, André van Eerde ${ }^{1}$, Jianguo Su ${ }^{2 *}$ and Jihong Liu Clarke ${ }^{1 *}$ \\ ${ }^{1}$ Division of Biotechnology and Plant Health, NIBIO - Norwegian Institute of Bioeconomy Research, Ås, Norway, ${ }^{2}$ Department \\ of Aquatic Animal Medicine, College of Fisheries, Huazhong Agricultural University, Wuhan, China
}

Aquaculture has undergone rapid development in the past decades. It provides a large part of high-quality protein food for humans, and thus, a sustainable aquaculture industry is of great importance for the worldwide food supply and economy. Along with the quick expansion of aquaculture, the high fish densities employed in fish farming increase the risks of outbreaks of a variety of aquatic diseases. Such diseases not only cause huge economic losses, but also lead to ecological hazards in terms of pathogen spread to marine ecosystems causing infection of wild fish and polluting the environment. Thus, fish health is essential for the aquaculture industry to be environmentally sustainable and a prerequisite for intensive aquaculture production globally. The wide use of antibiotics and drug residues has caused intensive pollution along with risks for food safety and increasing antimicrobial resistance. Vaccination is the most effective and environmentally friendly approach to battle infectious diseases in aquaculture with minimal ecological impact and is applicable to most species of farmed fish. However, there are only 34 fish vaccines commercially available globally to date, showing the urgent need for further development of fish vaccines to manage fish health and ensure food safety. Plant genetic engineering has been utilized to produce genetically modified crops with desirable characteristics and has also been used for vaccine production, with several advantages including costeffectiveness, safety when compared with live virus vaccines, and plants being capable of carrying out posttranslational modifications that are similar to naturally occurring systems. So far, plant-derived vaccines, antibodies, and therapeutic proteins have been produced for human and animal health. However, the development of plant-made vaccines for animals, especially fish, is still lagging behind the development of human vaccines. The present review summarizes the development of fish vaccines currently utilized and the suitability of the plant-production platform for fish vaccine and then addresses considerations regarding fish vaccine production in plants. Developing fish vaccines by way of plant biotechnology are significant for the aquaculture industry, fish health management, food safety, and human health.

Keywords: plant genetic engineering, aquaculture, fish vaccine, food security, application prospects 


\section{INTRODUCTION}

Aquatic products including fishes, crustaceans, and other miscellaneous aquatic animals are excellent animal protein sources and contain a great variety of nutrients which are essential for humans (Adams, 2019). Among these species, fishes and fish source products are the most consumed. Fisheries also play an important role in the livelihoods of millions of people worldwide. Currently, the most important methods to obtain fishes or other aquatic products are capture from seawater or freshwater and aquaculture. Fish, crustaceans, mollusks, and aquatic plants can all be cultured in aquaculture industries; of these, fish farming is the most important (Evensen, 2016).

The global fishery production (capture and aquaculture) reached 206.5 million tons in 2017 and increased to 211.9 million tons in 2018. Aquaculture has expanded impressively in the past several decades and has become the major global fish industry with over $50 \%$ of the total fishery production with 112.2 million tons in 2017, increasing to 114.5 million tons in 2018 (FAO, 2021). Production of aquaculture finfish (including marine fishes, diadromous fishes, and freshwater fishes) constituted a large part of the total production, amounting to 52.7 million tons in 2017 and 54.3 million tons in 2018 (FAO, 2021). ${ }^{1}$ Aquatic products are mostly from Asia, in particular China, which covers over $70 \%$ of global aquaculture production with a great increase (99.6 million tons in 2014-120.1 million tons in 2019, FAO, 2021; see footnote 1) in these years. It is estimated that in this decade, total production from both capture and aquaculture will exceed that of beef, pork, or poultry due to the high global demand for food fish (Clarke et al., 2013). The rapid development of aquaculture could contribute to the UN sustainable development goals [SDGs, especially SDGs 1 (no poverty), 2 (zero hunger), 3 (good health and wellbeing), 14 (life under water), and 15 (life on land)]. ${ }^{2}$

Since the rapid advance of aquaculture, the high densities and other artificial conditions (artificial propagation, polyculture, transportation etc.) in which fish are farmed exponentially increase the risks of outbreaks from infectious diseases. There may also be an ecological hazard in terms of pathogen spread to wild fish (Visuthismajarn et al., 2005). It is estimated that approximately $10 \%$ of cultured aquatic animal production are lost due to infectious diseases globally, leading to over 10 billion USD economic waste (Adams, 2019). Outbreaks of diseases in Atlantic salmon (Salmo salar), oyster and marine shrimp have led to partial or sometimes total loss of production in several countries worldwide. Natural disasters, diseases, and pollution have together caused serious production loss globally (Su et al., 2021).

Aquatic diseases also threaten human livelihood and health by reducing food security. Unhealthy aquatic production and drug residues from production may have harmful effects on humans and the environment. People increasingly pay attention to the quality and safety of aquatic products and the risk to these from environmental pollution. To control disease

${ }^{1}$ http://www.fao.org

${ }^{2} \mathrm{http}: / /$ www.globalgoals.org/ occurrence, chemicals and antibiotics are employed. Antibiotics, such as florfenicol, norfloxacin, and flavomycin, can protect farmed fish from bacterial diseases efficiently and cost-effectively. However, these may pose serious risks to the environment, human health, and food security (Sneeringer et al., 2019). Drug residues with the potential risk of drug resistance, allergic reactions, and poisoning reactions seriously endanger the farmed species, the environment, and human health, for which the emerging antimicrobial resistance (AMR) has become a global threat (Svoboda, 2020). Therefore, health management of aquaculture is of great importance for food security, food safety, the environment, and sustainable development of the aquaculture industry. Moreover, candidate alternatives, e.g., probiotics and plant bioactive compounds to replace antibiotics, could also be promising, contributing to the management of aquaculture fish health (Yao et al., 2020).

To secure the sustainability and expansion of global aquaculture production, fish vaccination has been proven highly effective and safe, protecting fish from diseases with minimal ecological impact and being applicable to all species of farmed fishes. Vaccination is the mainstream technology for fish disease prophylaxis worldwide and the normative production standard for international modern aquaculture. Since the 1980s, development of fish vaccines has made significant progress. The number of commercial vaccines available for use in fish expanded from two in the 1980s to 34 currently (Shefat, 2018). Up to 2020, over 140 fish vaccines have received approval globally, according to incomplete statistics (Jeong et al., 2020). Vaccine types mainly include live vaccines, inactivated vaccines, and genetically engineered vaccines. Recombinant subunit vaccines, one kind of genetically engineered vaccine, represent promising options for high safety, high stability, easy production, easy control, and good immunogenicity (Su and Su, 2018). Subunit antigens have been produced in bacteria, yeast, transgenic plants, insects, mammalian cell cultures, and cell-free platforms.

In the present review, we summarize the development status of fish vaccines and describe the potential of plant biotechnological engineering for their further development.

\section{FISH VACCINE DEVELOPMENT}

Intensive and large-scale fish farming has created conditions in which rapid spread and vast outbreaks of all kinds of infectious fish diseases can occur (Adams, 2019). Due to the challenges in development of vaccines, a large number of drugs, especially antibiotics, have been widely used in fish farms to improve fish growth and enhance productivity (Adams, 2019). However, the utilization of antibiotics in aquaculture results in drug residues, leading to environmental pollution seriously threatening not only ecological safety but also human health. Additionally, it exacerbates the global AMR threat (Svoboda, 2020).

Fish have an integrated immune system including an innate immune system and an adaptive immune system. Both innate and adaptive immune systems are essential for vaccination to 
trigger an immune response. In 1942, inactivated Aeromonas salmonicida orally immunized rainbow trout (Oncorhynchus mykiss) as the first fish vaccine (Duff, 1942). Researchers have since made extensive studies to prepare different kinds of vaccines to control fish diseases caused by virus, bacteria, or parasites. Large numbers of vaccines have been reported for Atlantic salmon, rainbow trout, sea bass (Dicentrarchus labrax), sea bream (Sparus aurata), tilapia (Oreochromis niloticus/ mossambicus), amberjack (Seriola dumerili), yellowtail (Seriola quinqueradiata), catfish (Ictalurus punctatus), and Vietnamese catfish (Pangasianodon hypophthalmus; Clarke et al., 2013; Assefa and Abunna, 2018). There are currently over 30 commercially available vaccines against major infectious bacterial and viral diseases of fish, including Arthrobacter vaccine, Vibrio anguillarum-ordalii, A. salmonicida bacterin, Yersinia ruckeri bacterin, and other vaccines against bacteria in salmonids, Flavobacterium columnare vaccine, and E. ictaluri bacterin against bacteria in grouper, infectious pancreatic necrosis virus (IPNV) vaccine, infectious salmon anemia vaccine, nodavirus vaccine, and other vaccines against viruses in salmonids and seabass, Streptococcus agalactiae vaccine, and Streptococcus iniae vaccine against tilapia Streptococcosis, as well as spring viremia of carp vaccine, koi herpes virus (KHV) vaccine, grass carp hemorrhage disease vaccine, and other vaccines against viruses in carps (Shefat, 2018).

Fish vaccines are normally classified into three types based on preparation methods; these are live vaccine, inactivated vaccine, and genetically engineered vaccine (Table 1). Live vaccines are prepared with pathogens managed by attenuation or mutated attenuation. Inactivated vaccines are inactivated pathogenic microorganisms that remain immunogenic. They have the ability to induce specific resistance in aquatic animals after inoculation. For genetically engineered vaccines, different types include recombinant subunit vaccines, DNA vaccines, gene deletion/mutant vaccines, and live-vector vaccines. The most widely applied fish vaccines currently are inactivated and live attenuated vaccines (Ma et al., 2019), for example, KHV inactivated vaccine, SVCV inactivated vaccine, carp herpes virus live vaccine, and GCRV live vaccine ( $\mathrm{Su}$ and $\mathrm{Su}, 2018)$. Both types have some disadvantages. Inactivated vaccines require large numbers of antigens with high cost, while attenuated live vaccines are associated with long-term biosafety concerns from the risk of reversion to virulence and also stability issues due to their sensitivity to temperature and light ( $\mathrm{Su}$ and $\mathrm{Su}, 2018$ ).

Delivery methods for fish vaccines include injection, immersion, and oral administration. Intramuscular or intraperitoneal injection is the most popular method, providing an exact vaccination dosage and regulating systemic immune responses, but it usually causes large fish stress responses and is time-consuming, laborious, and relatively expensive (Corbeil et al., 2000). For immersion, the mechanism of fish vaccination during immersion immunization is still uncertain. However, vaccine concentration, immersion time, aquatic animal size, adjuvants, antigenic forms, and water temperature are all factors affecting the uptake of the soaked immune antigens by the hosts ( $\mathrm{Su}$ and $\mathrm{Su}, 2018$ ).
TABLE 1 | Comparison of three types of vaccines and delivery methods.

\begin{tabular}{|c|c|c|c|}
\hline & Live vaccine & $\begin{array}{l}\text { Inactivated } \\
\text { vaccine }\end{array}$ & Subunit vaccine \\
\hline $\begin{array}{l}\text { Preparation } \\
\text { method }\end{array}$ & $\begin{array}{l}\text { Attenuation/ } \\
\text { mutated } \\
\text { attenuation }\end{array}$ & Inactivated & Recombinant \\
\hline $\begin{array}{l}\text { Common delivery } \\
\text { method }\end{array}$ & $\begin{array}{l}\text { Injection/ } \\
\text { immersion }\end{array}$ & $\begin{array}{l}\text { Injection/ } \\
\text { immersion }\end{array}$ & $\begin{array}{l}\text { Injection/ } \\
\text { immersion/oral } \\
\text { administration }\end{array}$ \\
\hline $\begin{array}{l}\text { Administration } \\
\text { ease }\end{array}$ & Laborious & Laborious & $\begin{array}{l}\text { Convenient for oral } \\
\text { administration }\end{array}$ \\
\hline Immunity duration & 6-12 months & 6-12 months & $\begin{array}{l}\text { Depends on } \\
\text { delivery method }\end{array}$ \\
\hline Cost & High cost & High cost & Cost-effective \\
\hline \multirow[t]{5}{*}{ Advantages } & $\begin{array}{l}\text { Generally } \\
\text { attenuated } \\
\text { vaccine; }\end{array}$ & $\begin{array}{l}\text { Short } \\
\text { development } \\
\text { cycle; }\end{array}$ & $\begin{array}{l}\text { Excellent safety; } \\
\text { Simple production; } \\
\text { Easy control; }\end{array}$ \\
\hline & $\begin{array}{l}\text { Close to natural } \\
\text { infection; }\end{array}$ & $\begin{array}{l}\text { Safe to use; and } \\
\text { Easy to preserve }\end{array}$ & $\begin{array}{l}\text { High stability; High } \\
\text { purity and Good } \\
\text { immunogenicity; }\end{array}$ \\
\hline & $\begin{array}{l}\text { Effectively } \\
\text { stimulates } \\
\text { immune system; }\end{array}$ & & $\begin{array}{l}\text { The most } \\
\text { promising vaccine } \\
\text { and Low-cost }\end{array}$ \\
\hline & $\begin{array}{l}\text { Pathogen can } \\
\text { reproduce in vivo; }\end{array}$ & & $\begin{array}{l}\text { Important direction } \\
\text { of vaccine }\end{array}$ \\
\hline & $\begin{array}{l}\text { Low dosage; No } \\
\text { adjuvant needed; } \\
\text { and } \\
\text { Long protection } \\
\text { duration }\end{array}$ & & development \\
\hline \multirow[t]{5}{*}{ Limitations } & $\begin{array}{l}\text { Inconvenient } \\
\text { storage and } \\
\text { transportation; }\end{array}$ & $\begin{array}{l}\text { Cannot reproduce } \\
\text { after } \\
\text { immunization; }\end{array}$ & $\begin{array}{l}\text { Highly affected by } \\
\text { the expression } \\
\text { system; }\end{array}$ \\
\hline & $\begin{array}{l}\text { Poor safety under } \\
\text { natural conditions; } \\
\text { and }\end{array}$ & $\begin{array}{l}\text { Large } \\
\text { immunization } \\
\text { dosage; }\end{array}$ & $\begin{array}{l}\text { Uncertain immune } \\
\text { response caused } \\
\text { by the vaccine; }\end{array}$ \\
\hline & Short shelf life & $\begin{array}{l}\text { Short duration; } \\
\text { and }\end{array}$ & $\begin{array}{l}\text { Tissue distribution } \\
\text { and expression still } \\
\text { unknown; }\end{array}$ \\
\hline & & \multirow{2}{*}{$\begin{array}{l}\text { Appropriate } \\
\text { adjuvant is } \\
\text { needed }\end{array}$} & $\begin{array}{l}\text { Uncertain stability; } \\
\text { Immune tolerance; }\end{array}$ \\
\hline & & & $\begin{array}{l}\text { Short protection } \\
\text { duration; and Not } \\
\text { many successful } \\
\text { cases }\end{array}$ \\
\hline
\end{tabular}

Since aquatic animals live in an environment inseparable from water and are cultured in large bodies of water, oral immunization is considered to be the most ideal vaccination method for fish and other aquaculture animals. Oral vaccination provides a non-stressful and energy-saving administration for both fish and farmers (Embregts and Forlenza, 2016). However, oral vaccination procedures are difficult to standardize. The large surface area of the intestine increases the possibility of antigen breakdown in the gastro-intestinal tract, leading to mostly local mucosal immune responses and immune tolerance. Vaccination dosage, vaccination regime, antigen formulation, encapsulation, adjuvants, and the identity of the fish species are all necessary factors to be considered for oral administration, and further research is needed to achieve a balance between immune responses and tolerance (Embregts et al., 2019). 
Oral vaccination along with commercial feed of Escherichia coli derived orange-spotted grouper nervous necrosis virus (NNV) virus-like particle (VLP) vaccine was able to offer over $50 \%$ survival against NNV infection (Chien et al., 2018). Lyophilized recombinant yeast producing red grouper nervous necrosis virus capsid protein as diet for groupers is reported to be feasible for vaccination (Cho et al., 2017).

Each kind of vaccine has its own advantages and shortcomings, and the choice of vaccine and delivery method is largely dependent on characteristics of the farmed fish species, such as size, feeding habits, culture temperature, and economic value. Pathogens and protection required also need to be considered. Economic cost is another essential factor for aquaculture industries, mostly related to the value of farmed fish.

Future fish vaccines against infectious pathogens, including viruses, bacteria, fungi, and parasites, in modern aquaculture industries should be cost-effective and environmentally friendly. They should allow for large-scale production and also be available and suitable for small fish farmers. Application of plant biotechnological techniques in fish vaccine development could satisfy these requirements for fish vaccination.

\section{PLANT-BASED VACCINE DEVELOPMENT AND APPLICATION}

In molecular farming, recombinant proteins are produced in plants with the express intention to utilize the protein itself rather than any trait or capability it confers on the plant. Whole plants or plant cells/tissues cultured in vitro are used to express valuable recombinant proteins. This technique has been established as an economically viable alternative to mainstream production systems, such as microbes and mammalian cells cultivated in large-scale bioreactors (Clarke et al., 2013; Bock, 2015; Buyel et al., 2017; Dobrica et al., 2017; Castells-Graells and Lomonossoff, 2021). The initial attempts made to produce recombinant proteins in plants were in 1986 and 1989 (Barta et al., 1986; Hiatt et al., 1989). Utilization of plants for molecule production was initially adopted for biopharmaceutical proteins. Plant-produced human enzyme has been commercialized since 2012 (Rosales-Mendoza et al., 2017; van Eerde et al., 2020; Siriwattananon et al., 2021). A large number of pre-clinical and clinical studies of plantmade human and animal recombinant pharmaceutical proteins have proved the feasibility, efficacy, and safety of plant factories for vaccines (Takeyama et al., 2015).

As distinct from microbes or mammalian cell expression, a plant-based platform offers attractive advantages for recombinant subunit vaccines (Clarke et al., 2013; RosalesMendoza et al., 2017; Buyel, 2019): (1) It is an environmentally friendly vaccine production platform using free solar energy and capturing $\mathrm{CO}_{2}$, with low energy requirements and lacking greenhouse gas emissions reducing the cost of vaccines. (2) Plant-based systems can be used to produce vaccines for oral delivery which do not require sophisticated bioreactors and complex downstream processing, thereby becoming a more economical system than the conventional expression systems, e.g., E. coli (Avesani et al., 2010) and baculovirus-infected insect cells (Avesani et al., 2013). Hence, scaling-up of production is cheaper and the scale is not restricted by the size and number of available bioreactors (Daniell et al., 2015; Abiri et al., 2016). (3) Plant systems are safe. Plant-made subunit vaccines do not have the safety concerns of live vaccines (Su and Su, 2018). Moreover, undesirable or toxic components, such as bacterial endotoxins and hyperglycosylated proteins from yeast, have not been found in plant-derived systems, in contrast to mammalian-based production systems. (d) Plantbased systems possess a high capacity for biosynthesis, similar to naturally occurring systems, to perform posttranslational modification, such as glycosylation and complex folding and assembly, increasing vaccine immunogenicity (Kim et al., 2009; Guan et al., 2013; Lai and Qiang, 2013; Aboulata et al., 2014). On the other hand, plant-based platforms still possess disadvantages in uncertain efficiency of modifications including glycosylation, methylation, polymerization, quantity and quality of recombinant proteins, and dosage of vaccines in tissues (Erna et al., 2016).

Plenty of vaccine antigens, monoclonal antibodies (mAbs), and other biopharmaceuticals have been produced using three different plant biotechnology platforms: transient expression of transgenes in plants mediated by viral vectors, stable nuclear expression of transgenes in the nuclear genome of transgenic plants or cell cultures, and stable expression of transgenes in the plastid (chloroplast) genome of transplastomic plants (Daniell et al., 2009; Streatfield, 2010; Lössl and Waheed, 2011; Maliga and Bock, 2011; Clarke et al., 2013).

Each system has its advantages and limitations, and the choice of technique is largely dependent on the required production. Meanwhile, the regulatory issues of plant-made recombinant proteins and good manufacturing practice have also been well developed.

Various species of plants are available for plant molecular farming. Plastid genome engineering of edible plants has been utilized to produce a great many kinds of foreign proteins in lettuce, tomato, potato, cabbage, etc. (Ruf et al., 2001; Kanamoto et al., 2006; Cardi et al., 2010). A chloroplast expression system has been reported to be a promising production system for oral vaccines (Davoodi-Semiromi et al., 2010; Verma et al., 2010). Transgenic plants have been used to produce vaccines against viruses, bacteria, and parasites (Specht et al., 2010; Guan et al., 2013). Vaccine production in algae is another system used for transient expression and there are also some good examples of algal-produced biopharmaceuticals (VidalMeireles et al., 2017; Tabatabaei et al., 2019).

Microalgae offer health-promoting benefits as a nutritional supplement in feed meal for their digestibility, high contents of proteins, lipids, and essential nutrients, and potential immunogenicity (Charoonnart et al., 2018). Microalgae can be a viable protein production and oral delivery system to vaccinate fish. Genetic engineering technologies in microalgae offer the possibility of producing "functional feed additives" with no need for complex post-expression conditions, such as purification, cold chain, and injection (Kwon et al., 2019). Chlamydomonas reinhardtii, Dunaliella salina, cyanobacteria, 
and other microalgae have been processed to express antigen genes in chloroplasts for the prevention and control of infectious diseases (Ma et al., 2020b). Although several species of microalgae have been widely used in the aquaculture industry, many of them have not yet become established as an effective and mature genetic manipulation system. ${ }^{3}$

Vaccine development in plants has been covered in a number of reviews (Rybicki, 2014; Takeyama et al., 2015; Erna et al., 2016; Capell et al., 2020; Tuse et al., 2020). Human plant-based vaccines are not yet commercialized, while numerous subunit vaccine attempts are being performed in transgenic plants (Floss et al., 2007; He et al., 2008; Erna et al., 2016; Rosales-Mendoza et al., 2017). Hepatitis C virus E1E2 and its mutant E1E2 $\Delta$ N6 have been produced in lettuce with a transient gene expression system and correctly processed and glycosylated. Oral vaccination with the lettuce induced vaccine-stimulated secretion of $\operatorname{IgA}$ (Immunoglobulin A) in mice (Clarke et al., 2017). This study provided the evidence that complex viral antigen could be produced, processed, and functionally modified in edible plants. Plant-made vaccines have been widely reported against rabies (Ashraf et al., 2005; Loza-Rubio et al., 2008; Roy et al., 2010; Loza-Rubio et al., 2012), porcine reproductive and respiratory syndrome virus, and porcine post-weaning diarrhea in piglets (Chen and Liu, 2011; Kolotilin et al., 2012). A tobacco-made Newcastle disease vaccine for poultry is the only plant-made vaccine approved by the United States Department of Agriculture so far (Hahn et al., 2007; Li et al., 2007; Yang et al., 2007; Joensuu et al., 2008; Gómez et al., 2009; Van Eck and Keen, 2009; Wu et al., 2009; Ma et al., 2020a). Plant-made veterinary vaccines have also been studied in mink, dogs, and cats (Dalsgaard et al., 1997; Molina et al., 2004, 2005; Rybicki, 2010).

Plant-based vaccines are ideal for oral administration. The manufacturing process is simple and there is no additional medical device needed for injection. Plant-based vaccines with high purity make vaccination more convenient and induce stronger immune responses. Vaccine antigens ingested by oral administration go through the gastric environment and to the intestine and are absorbed by $\mathrm{M}$ cells in the follicle-associated epithelium, inducing mucosal and systemic immune responses (Holmgren and Czerkinsky, 2005; Lamichhane et al., 2014; Tatsuhiko et al., 2014). Moreover, vaccines based on edible plants, such as lettuce, potato, tomato, corn, and rice, provide a needleless, convenient, and easy route of administration (Tacket, 2009). Lettuce is a potentially ideal plant base for oral vaccines and several human therapeutic proteins have been expressed at high levels in lettuce chloroplasts, e.g., oral vaccine from lettuce chloroplasts against dengue fever (Ruhlman et al., 2007, 2010; Davoodi-Semiromi et al., 2010; Boyhan and Daniell, 2011; Kanagaraj et al., 2011; Lakshmi et al., 2013; van Eerde et al., 2019).

\footnotetext{
${ }^{3}$ https://thefishsite.com/articles/boost-for-algae-based-oral-vaccines; https://www. aquaculturenorthamerica.com/algae-based-vaccine-for-aquaculture-in-theworks-1804/; https://www.enabling-project.com/news-1/2020/2/11/algae-for-fishvaccine
}

Regulatory constraints are another obstacle for commercial GM plants worldwide, especially in Europe. Utilization of Agrobacterium for transformation or plant antigens, transgene containment and long-term stability under room temperature add to regulatory and production costs (Yusibov et al., 2011). Production in an open field system lowers production costs but adds significant regulatory costs for large-scale field research. Stable expression of virus subunits in chloroplasts does not use Agrobacterium, and without involving any plant pathogenic sequences are an ideal approach to minimize regulatory cost (Huebbers and Buyel, 2021). Meanwhile, avoiding production in seeds and using a greenhouse could effectively reduce costs in regulatory approval.

\section{THE POTENTIAL FOR PLANT-MADE FISH VACCINES}

For new fish vaccines, economic cost is one of the most important factors due to the nature of aquaculture with high farming cluster density and large scale. Plants provide a production platform for vaccines with high cost-effectiveness, efficiency, and safety (Ma et al., 2019). Despite having a higher monetary cost than antibiotics, plant-based vaccine production systems are still a cost-effective and promising approach offering efficient and safe vaccines to protect fish health and manage the sustainable development of fast-growing aquaculture globally. Diversity of fish species, type of fish diseases, characteristics of the vaccine target, timeline, scaling-up potential, resources, biosafety concerns, future commercial perspective, feeding habits of fish, and management difficulty also need to be considered prior to selection of a plant expression system for fish vaccine production.

The number of studies into the use of plants for the production of subunit vaccines for fish is still small but growing (Marsian et al., 2019; Su et al., 2021). Fish vaccines made in edible plants offer great potential for oral vaccination in aquaculture. A plant-generated recombinant subunit vaccine could also provide several antigen proteins simultaneously (Buyel, 2019). However, no plant-produced fish vaccine has been commercialized to date (Table 2). Therefore, it is extremely necessary with further research on fish vaccine production using plant biotechnology.

Oral vaccination provides a non-stressful and energy-saving administration for both fish and farmers (Embregts and Forlenza, 2016). Vaccination via feeding appears to be an ideal method to provide protective immunity without extortionate cost of time and effort. Although taking into account the vaccination dosage and the cost of plant treatment including homogenization, drying, and briquetting, the use of edible plants for production of pathogen subunits decreases the need for expensive fermentation, purification, cold storage, transportation, and sterile delivery (Clarke et al., 2017), and oral recombinant plant-produced vaccine has the advantages of simplicity and safety. Thus, oral vaccine produced in edible crops offers unique cost advantages and antigen stability at room temperature. 
TABLE 2 | Representative commercial fish vaccines and plant-produced fish vaccines under development.

\begin{tabular}{|c|c|c|c|c|c|c|}
\hline Species & $\begin{array}{l}\text { Disease or } \\
\text { pathogen }\end{array}$ & Vaccine antigen & $\begin{array}{l}\text { Production } \\
\text { platform }\end{array}$ & Delivery route & $\begin{array}{l}\text { Commercially } \\
\text { available }\end{array}$ & Producer/reference \\
\hline Salmonids & $\begin{array}{l}\text { Infectious pancreatic } \\
\text { necrosis virus (IPNV) }\end{array}$ & Inactivated virus & Inactivated & Intraperitoneal & Yes & Centrovet, Chile \\
\hline Salmonids & $\begin{array}{l}\text { Infectious } \\
\text { hematopoietic } \\
\text { necrosis virus (IHNV) }\end{array}$ & $\begin{array}{l}\text { Recombinant G } \\
\text { protein }\end{array}$ & DNA vaccine & Intramuscular & Yes & $\begin{array}{l}\text { Aqua Health Ltd., } \\
\text { Novartis, Canada }\end{array}$ \\
\hline Salmonids & $\begin{array}{l}\text { Salmon alphaviruses } \\
\text { (SAV) }\end{array}$ & Inactivated virus & Inactivated & Intraperitoneal & Yes & $\begin{array}{l}\text { Pharmaq AS, Norway } \\
\text { Intervet-International } \\
\text { BV, Netherlands }\end{array}$ \\
\hline Koi carp & $\begin{array}{l}\text { Koi herpes virus } \\
\text { disease }\end{array}$ & Attenuated virus & Attenuated & Immersion/injection & Yes & $\begin{array}{l}\text { KoVax Ltd., } \\
\text { Jerusalem, Israel }\end{array}$ \\
\hline Grass carp & Grass carp reovirus & Attenuated virus & Attenuated & Injection & Yes & Dahuanong, China \\
\hline Channel catfish & Edwardsiella ictaluri & Attenuated bacteria & Attenuated & Immersion & Yes & $\begin{array}{l}\text { Mississippi state } \\
\text { university, } \\
\text { United States }\end{array}$ \\
\hline Grouper & $\begin{array}{l}\text { Red grouper nervous } \\
\text { necrosis virus } \\
\text { (RGNNV) }\end{array}$ & Capsid protein & Yeast & Oral & No & Cho et al., 2017 \\
\hline Grouper & $\begin{array}{l}\text { Orange-spotted } \\
\text { grouper nervous } \\
\text { necrosis virus } \\
\text { (OSGNNV) }\end{array}$ & VLP & E. coli & Oral & No & Chien et al., 2018 \\
\hline Rainbow trout & IPNV; IHNV & IPNV VP2 & $\begin{array}{l}\text { RNA polymerase II } \\
\text { system }\end{array}$ & Intraperitoneal & No & Guo et al., 2018 \\
\hline Salmonids & $\begin{array}{l}\text { Cardiomyopathy } \\
\text { syndrome (PMCV) }\end{array}$ & ORF1 & $\begin{array}{l}\text { Nicotiana } \\
\text { benthamiana }\end{array}$ & Intraperitoneal & No & Su et al., 2021 \\
\hline Salmonids & $\begin{array}{l}\text { Atlantic cod nervous } \\
\text { necrosis virus } \\
\text { (ACNNV) }\end{array}$ & VLP & N. benthamiana & Intramuscular & No & Marsian et al., 2019 \\
\hline
\end{tabular}

By means of a plant expression system, VLPs assembled from viral capsid proteins mimicking natural viral tertiary structure (Rosenthal et al., 2014) have become an ideal advanced subunit vaccine candidate for fish vaccine. VLPs do not contain genetic material, avoiding the possibility of reversion mutations or pathogenic infection (Noad and Roy, 2003). However, VLPs can potentiate host immune responses by recognizable repetitive subunits triggering cellular and humoral responses (Keller et al., 2010). VLP vaccines have been licensed and commercialized in humans, such as Cervarix [human papillomavirus (HPV)], Merck's Recombivax HB [Hepatitis B virus (HBV)], and Gardasil (HPV; Yusibov et al., 2011). There has been increasing interest in VLP vaccination of fish. Injection of NNV VLP vaccines produced by $E$. coli, yeast, baculovirus, and plant or cell-free self-assembled expression has been tested to elicit immune responses in fish, stimulating specific antibody secretion and triggering full-scale immune response (Lin et al., 2001; Liu et al., 2006; Lai et al., 2014; Luu et al., 2017). Oral VLP vaccines against grouper NNV can stimulate specific antibody production and provide over $50 \%$ protection against NNV challenge (Cho et al., 2017; Chien et al., 2018). Yeast expressed IPNV capsid protein VP2 subviral particle (SVP) vaccine in rainbow trout has been developed inducing specific antibody secretion, proving its immunogenicity (Dhar et al., 2010). IPNV VP2 protein recombinant vaccines against both IPNV and IHNV (infectious hematopoietic necrosis virus) have been shown to trigger IgM production against both pathogens (Guo et al., 2018). A plant-made VLP vaccine against piscine myocarditis virus (PMCV) in wild Atlantic salmon, the causative agent of cardiomyopathy syndrome, was produced in Nicotiana benthamiana by transient expression and reported recently by our laboratory. PMCV VLP vaccine provided limited protection against PMCV infection. Industrial scale fish vaccination trials have demonstrated the potential and also challenges encountered (Su et al., 2021). VLPs of Atlantic cod nervous necrosis virus (ACNNV) were successfully produced by transient expression in $N$. benthamiana and have been shown to provide efficient protection against virus challenge in sea bass (D. labrax; Marsian et al., 2019). The aforementioned research demonstrates the ability of VLP to be an ideal alternative vaccine candidate to conventional inactivated or attenuated live vaccines. Plant expression systems are a great option for VLP production with the special advantages of plant biotechnology. Thus, plant-made VLP vaccines are promising for fish viral diseases, raising hopes of their use in the near future.

Based on the experience from human vaccines produced in plants, the development of fish vaccines in edible crops or non-food crops for oral vaccination has great application potential. The few examples mentioned above strongly suggest that development of fish vaccine by plant biotechnology needs further research efforts to advance cost-effective fish health management and a sustainable aquaculture industry.

\section{CONCLUSION}

Research on plant-based vaccines focusses mostly on increasing the amount and purity of antigen in transgenic plants to 
stimulate adequate immune responses. Targeting the most suitable subcellular compartment in plant cells is also of great importance for optimal quantity and quality of antigen. At present, production and application of plant-made vaccines still face several challenges, yet the promise and potential of better plant-based vaccines are attractive. Plant-based vaccine is an emerging type of vaccine and it is anticipated that regulatory approval will be granted eventually.

Because of the increase of both global population and food safety demand, aquatic health management is important worldwide. Plant-based fish vaccines could provide low-cost, high safety, and effective protection for farmed fish species. However, development of plant-made fish vaccine is still lagging behind efforts in producing plant-made vaccines for use in humans and non-aquatic animals. The present review has summarized the status of fish vaccine management and the application of plant genetic engineering in fish vaccine production. Plant-made recombinant protein vaccine using oral administration shows special advantages in production and vaccination. However, plant-made vaccine has not yet been approved for oral delivery.

\section{REFERENCES}

Abiri, R., Valdiani, A., Maziah, M., Shaharuddin, N. A., Sahebi, M., Yusof, Z. N. B., et al. (2016). A critical review of the concept of transgenic plants: insights into pharmaceutical biotechnology and molecular farming. Curr. Issues Mol. Biol. 18, 21-42. doi: 10.21775/cimb.018.021

Aboulata, A., Vitti, A., Nuzzaci, M., Elattar, A. K., Piazzolla, G., Tortorella, C., et al. (2014). Plant-based vaccines: novel and low-cost possible route for mediterranean innovative vaccination strategies. Adv. Virus Res. 89:1. doi: 10.1016/B978-0-12-800172-1.00001-X

Adams, A. (2019). Progress, challenges and opportunities in fish vaccine development. Fish Shellfish Immunol. 90, 210-214. doi: 10.1016/j.fsi.2019.04.066

Ashraf, S., Singh, P., Yadav, D. K., Shahnawaz, M., Mishra, S., Sawant, S. V., et al. (2005). High level expression of surface glycoprotein of rabies virus in tobacco leaves and its immunoprotective activity in mice. J. Biotechnol. 119, 1-14. doi: 10.1016/j.jbiotec.2005.06.009

Assefa, A., and Abunna, F. (2018). Maintenance of fish health in aquaculture: review of epidemiological approaches for prevention and control of infectious disease of fish. Vet. Med. Int. 2018:5432497. doi: 10.1155/2018/5432497

Avesani, L., Bortesi, L., Santi, L., Fa Lorni, A., and Pezzotti, M. (2010). Plantmade pharmaceuticals for the prevention and treatment of autoimmune diseases: where are we? Exp. Rev. Vaccin. 9, 957-969. doi: 10.1586/erv.10.82

Avesani, L., Merlin, M., Gecchele, E., Capaldi, S., and Pezzotti, M. (2013). Comparative analysis of different biofactories for the production of a major diabetes autoantigen. Transgenic Res. 23, 281-291. doi: 10.1007/ s11248-013-9749-9

Barta, A., Sommergruber, K., Thompson, D., Hartmuth, K., Matzke, M. A., and Matzke, A. J. M. (1986). The expression of a nopaline synthase - human growth-hormone chimeric gene in transformed tobacco and sunflower callustissue. Plant Mol. Biol. 6, 347-357. doi: 10.1007/BF00034942

Bock, R. (2015). Engineering plastid genomes: methods, tools, and applications in basic research and biotechnology. Annu. Rev. Plant Biol. 66, 211-241. doi: 10.1146/annurev-arplant-050213-040212

Boyhan, D., and Daniell, H. (2011). Low-cost production of proinsulin in tobacco and lettuce chloroplasts for injectable or oral delivery of functional insulin and C-peptide. Plant Biotechnol. J. 9, 585-598. doi: $10.1111 /$ j.1467-7652.2010.00582.x

Buyel, J. F. (2019). Plant molecular farming integration and exploitation of side streams to achieve sustainable biomanufacturing. Front. Plant Sci. 9:17. doi: $10.3389 /$ fpls.2018.01893
In conclusion, for future fish vaccines, plant biotechnology provides a perfect option for production and vaccination. More research should be carried out to meet this urgent need.

\section{AUTHOR CONTRIBUTIONS}

HS and JC initiated and designed the overall concept and wrote the manuscript. All authors revised the manuscript, approved the final version, and approved it for publication.

\section{FUNDING}

This work was supported by the EEA grants 2014-2021, the SmartVac project no. 1/2019, the Research Council of Norway and National Natural Science Foundation of China co-funded Feed2Food project grant no. 319693, the Norwegian Ministry of Foreign Affairs through the Royal Norwegian Embassy in Beijing as part of the Sinograin II project (CHN 2152, 17/0019), and the NIBIO core funding to China collaboration (project no. 51133).

Buyel, J. F., Twyman, R. M., and Fischer, R. (2017). Very-large-scale production of antibodies in plants: The biologization of manufacturing. Biotechnol. Adv. 35, 458-465. doi: 10.1016/j.biotechadv.2017.03.011

Capell, T., Twyman, R. M., Armario-Najera, V., Ma, J. K. C., Schillberg, S., and Christou, P. (2020). Potential applications of plant biotechnology against SARS-CoV-2. Trends Plant Sci. 25, 635-643. doi: 10.1016/j. tplants.2020.04.009

Cardi, T., Lenzi, P., and Maliga, P. (2010). Chloroplasts as expression platforms for plant-produced vaccines. Expert Rev. Vaccines 9, 893-911. doi: 10.1586/ erv.10.78

Castells-Graells, R., and Lomonossoff, G. P. (2021). Plant-based production can result in covalent cross-linking of proteins. Plant Biotechnol. J. 19, 1095-1097. doi: $10.1111 /$ pbi.13598

Charoonnart, P., Purton, S., and Saksmerprome, V. (2018). Applications of microalgal biotechnology for disease control in aquaculture. Biology 7:14. doi: 10.3390/biology7020024

Chen, X., and Liu, J. (2011). Generation and immunogenicity of transgenic potato expressing the GP5 protein of porcine reproductive and respiratory syndrome virus. J. Virol. Methods 173, 153-158. doi: 10.1016/j. jviromet.2011.02.001

Chien, M.-H., Wu, S.-Y., and Lin, C.-H. (2018). Oral immunization with cellfree self-assembly virus-like particles against orange-spotted grouper nervous necrosis virus in grouper larvae, Epinephelus coioides. Vet. Immunol. Immunopathol. 197, 69-75. doi: 10.1016/j.vetimm.2018.01.012

Cho, S. Y., Kim, H. J., Nguyen Thi, L., Han, H.-J., Lee, D.-C., Hwang, J. Y., et al. (2017). Oral vaccination through voluntary consumption of the convict grouper Epinephelus septemfasciatus with yeast producing the capsid protein of red-spotted grouper nervous necrosis virus. Vet. Microbiol. 204, 159-164. doi: 10.1016/j.vetmic.2017.04.022

Clarke, J. L., Paruch, L., Dobrica, M.-O., Caras, I., Tucureanu, C., Onu, A., et al. (2017). Lettuce-produced hepatitis C virus E1E2 heterodimer triggers immune responses in mice and antibody production after oral vaccination. Plant Biotechnol. J. 15, 1611-1621. doi: 10.1111/pbi.12743

Clarke, J. L., Waheed, M. T., and Lössl, A. G. (2013). How can plant genetic engineering contribute to cost-effective fish vaccine development for promoting sustainable aquaculture? Plant Mol. Biol. 83, 33-40. doi: 10.1007/ s11103-013-0081-9

Corbeil, S., Kurath, G., and Lapatra, S. E. (2000). Fish DNA vaccine against infectious hematopoietic necrosis virus: efficacy of various routes of immunisation. Fish Shellfish Immunol. 10, 711-723. doi: 10.1006/fsim. 2000.0286 
Dalsgaard, K., Uttenthal, A., Jones, T. D., Xu, F., Merryweather, A., Hamilton, W. D. O., et al. (1997). Plant-derived vaccine protects target animals against a viral disease. Nat. Biotechnol. 15, 248-252. doi: 10.1038/nbt0397-248

Daniell, H., Singh, N. D., Mason, H., and Streatfield, S. J. (2009). Plant-made vaccine antigens and biopharmaceuticals. Trends Plant Sci. 14, 669-679. doi: 10.1016/j.tplants.2009.09.009

Daniell, H., Streatfield, S. J., and Rybicki, E. P. (2015). Advances in molecular farming: key technologies, scaled up production and lead targets. Plant Biotechnol. J. 13, 1011-1012. doi: 10.1111/pbi.12478

Davoodi-Semiromi, A., Schreiber, M., Nalapalli, S., Verma, D., Singh, N. D., Banks, R. K., et al. (2010). Chloroplast-derived vaccine antigens confer dual immunity against cholera and malaria by oral or injectable delivery. Plant Biotechnol. J. 8, 223-242. doi: 10.1111/j.1467-7652.2009.00479.x

Dhar, A. K., Bowers, R. M., Rowe, C. G., and Allnutt, F. (2010). Expression of a foreign epitope on infectious pancreatic necrosis virus VP2 capsid protein subviral particle (SVP) and immunogenicity in rainbow trout. Antivir. Res. 85, 525-531. doi: 10.1016/j.antiviral.2009.12.009

Dobrica, M.-O., Lazar, C., Paruch, L., Skomedal, H., Steen, H., Haugslien, S., et al. (2017). A novel chimeric hepatitis B virus S/preS1 antigen produced in mammalian and plant cells elicits stronger humoral and cellular immune response than the standard vaccine-constituent. S protein. Antivir. Res. 144, 256-265. doi: 10.1016/j.antiviral.2017.06.017

Duff, D. (1942). The oral immunization of trout against bacterium salmonicida. J. Immunol. 44, 87-94.

Embregts, C. W. E., and Forlenza, M. (2016). Oral vaccination of fish: lessons from humans and veterinary species. Dev. Comp. Immunol. 64, 118-137. doi: 10.1016/j.dci.2016.03.024

Embregts, C. W. E., Rigaudeau, D., Tacchi, L., Pijlman, G. P., Kampers, L., Vesely, T., et al. (2019). Vaccination of carp against SVCV with an oral DNA vaccine or an insect cells-based subunit vaccine. Fish Shellfish Immunol. 85, 66-77. doi: 10.1016/j.fsi.2018.03.028

Erna, L., Ling, A., Pei, W. Y., Yian, K. R., Azmi, M., and Sobri, H. (2016). Plant-based vaccines: production and challenges. J. Bot. 2016:4928637. doi: $10.1155 / 2016 / 4928637$

Evensen, Ø. (2016). "Development of fish vaccines: focusing on methods," in Fish Vaccines. Birkhäuser Advances in Infectious Diseases. ed. A. Adams (Basel: Springer).

FAO (2021). Food and Agriculture Organization of the United Nations. Available at: http://www.fao.org

Floss, D. M., Falkenburg, D., and Conrad, U. (2007). Production of vaccines and therapeutic antibodies for veterinary applications in transgenic plants: an overview. Transgenic Res. 16, 315-332. doi: 10.1007/s11248-007-9095-x

Gómez, E., Zoth, S. C., Asurmendi, , Rovere, C. V., and Berinstein, A. (2009). Expression of hemagglutinin-neuraminidase glycoprotein of Newcastle disease virus in agroinfiltrated Nicotiana benthamiana plants. J. Biotechnol. 144, 337-340. doi: 10.1016/j.jbiotec.2009.09.015

Guan, Z. J., Guo, H., YL, Z. P., et al. (2013). Recent advances and safety issues of transgenic plant-derived vaccines. Appl. Microbiol. Biotechnol. 97, 2817-2840. doi: 10.1007/s00253-012-4566-2

Guo, M. T., Shi, W., Wang, Y. X., Wang, Y. T., Chen, Y. P., Li, D. C., et al. (2018). Recombinant infectious hematopoietic necrosis virus expressing infectious pancreatic necrosis virus VP2 protein induces immunity against both pathogens. Fish Shellfish Immunol. 78, 187-194. doi: 10.1016/j.fsi.2018.04.047

Hahn, B. S., Jeon, I. S., Jung, Y. J., Kim, J. B., Parl, J. S., Ha, S. H., et al. (2007). Expression of hemagglutinin-neuraminidase protein of Newcastle disease virus in transgenic tobacco. Plant Biotechnol. Rep. 1, 85-92. doi: 10.1007/s11816-007-0012-9

He, Z., Du, X., Yao, W., and Dai, J. (2008). Pharmaceutical proteins produced in plant bioreactor in recent years. Afr. J. Biotechnol. 7, 4917-4925.

Hiatt, A., Cafferkey, R., and Bowdish, K. (1989). Production of antibodies in transgenic plants. Nature 342, 76-78. doi: 10.1038/342076a0

Holmgren, J., and Czerkinsky, C. (2005). Mucosal immunity and vaccines. Nat. Med. 11:S45. doi: 10.1038/nm1213

Huebbers, J. W., and Buyel, J. F. (2021). On the verge of the market - plant factories for the automated and standardized production of biopharmaceuticals. Biotechnol. Adv. 46:18. doi: 10.1016/j.biotechadv.2020.107681

Jeong, K. H., Kim, H. J., and Kim, H. J. (2020). Current status and future directions of fish vaccines employing virus-like particles. Fish Shellfish Immunol. 100, 49-57. doi: 10.1016/j.fsi.2020.02.060
Joensuu, J., Niklander-Teeri, V., and Brandle, J. (2008). Transgenic plants for animal health: plant-made vaccine antigens for animal infectious disease control. Phytochem. Rev. 7, 553-577. doi: 10.1007/s11101-008-9088-2

Kanagaraj, A. P., Verma, D., and Daniell, H. (2011). Expression of dengue-3 premembrane and envelope polyprotein in lettuce chloroplasts. Plant Mol. Biol. 76, 323-333. doi: 10.1007/s11103-011-9766-0

Kanamoto, H., Yamashita, A., Asao, H., Okumura, S., Takase, H., Hattori, M., et al. (2006). Efficient and stable transformation of Lactuca sativa L. cv. Cisco (lettuce) plastids. Transgenic Res. 15, 205-217. doi: 10.1007/ s11248-005-3997-2

Keller, S. A., Bauer, M., Manolova, V., Muntwiler, S., Saudan, P., and Bachmann, M. F. (2010). Cutting edge: limited specialization of dendritic cell subsets for MHC class II-associated presentation of viral particles. J. Immunol. 184, 26-29. doi: 10.4049/jimmunol.0901540

Kim, M. Y., Yang, M. S., and Kim, T. G. (2009). Expression of dengue virus E glycoprotein domain III in non-nicotine transgenic tobacco plants. Biotechnol. Bioprocess Eng. 14, 725-730. doi: 10.1007/s12257-009-3011-6

Kolotilin, I., Kaldis, A., Devriendt, B., Joensuu, J., Cox, E., and Menassa, R. (2012). Production of a subunit vaccine candidate against porcine postweaning diarrhea in high-biomass transplastomic tobacco. PLoS One 7:e42405. doi: 10.1371/journal.pone.0042405

Kwon, K. C., Lamb, A., Fox, D., and Jegathese, S. J. P. (2019). An evaluation of microalgae as a recombinant protein oral delivery platform for fish using green fluorescent protein (GFP). Fish Shellfish Immunol. 87, 414-420. doi: 10.1016/j.fsi.2019.01.038

Lai, Y.-X., Jin, B.-L., Xu, Y., Huang, L.-J., Huang, R.-Q., Zhang, Y., et al. (2014). Immune responses of orange-spotted grouper, Epinephelus coioides, against virus-like particles of betanodavirus produced in Escherichia coli. Vet. Immunol. Immunopathol. 157, 87-96. doi: 10.1016/j.vetimm.2013.10.003

Lai, H., and Qiang, C. (2013). Bioprocessing of plant-derived virus-like particles of Norwalk virus capsid protein under current good manufacture practice regulations. Plant Cell Rep. 32:1659. doi: 10.1007/s00299-0131484-4

Lakshmi, P. S., Verma, D., Yang, X., Lloyd, B., Daniell, H., and Cardona, P. J. (2013). Low cost tuberculosis vaccine antigens in capsules: expression in chloroplasts, bio-encapsulation, stability and functional evaluation in vitro. PLoS One 8:e54708. doi: 10.1371/journal.pone.0054708

Lamichhane, A., Azegami, T., and Kiyono, H. (2014). The mucosal immune system for vaccine development. Vaccine 32, 6711-6723. doi: 10.1016/j. vaccine.2014.08.089

Li, J., Chen, M., Liu, X., Zhang, H., Shen, F., and Wang, G. (2007). Transient expression of an active human interferon-beta in lettuce. Sci. Hortic. 112, 258-265. doi: 10.1016/j.scienta.2006.12.047

Lin, C. S., Lu, M. W., Tang, L., Liu, W. T., Chao, C. B., Lin, C. J., et al. (2001). Characterization of virus-like particles assembled in a recombinant baculovirus system expressing the capsid protein of a fish nodavirus. Virology 290, 50-58. doi: 10.1006/viro.2001.1157

Liu, W., Hsu, C. H., Chang, C. Y., Chen, H. H., and Lin, C. S. (2006). Immune response against grouper nervous necrosis virus by vaccination of virus-like particles. Vaccine 24, 6282-6287. doi: 10.1016/j.vaccine.2006.05.073

Lössl, A. G., and Waheed, M. T. (2011). Chloroplast-derived vaccines against human diseases: achievements, challenges and scopes. Plant Biotechnol. J. 9, 527-539. doi: 10.1111/j.1467-7652.2011.00615.x

Loza-Rubio, E., Rojas, E., Gomez, L., Olivera, M., and Gomez-Lim, M. (2008). Development of an edible rabies vaccine in maize using the Vnukovo strain. Dev. Biol. 131, 477-482.

Loza-Rubio, E., Rojas-Anaya, E., López, J., Olivera-Flores, M. T., Gómez-Lim, M., and Tapia-Pérez, G. (2012). Induction of a protective immune response to rabies virus in sheep after oral immunization with transgenic maize, expressing the rabies virus glycoprotein. Vaccine 30, 5551-5556. doi: 10.1016/j. vaccine.2012.06.039

Luu, V. T., Moon, H. Y., Hwang, J. Y., Kang, B. K., and Kang, H. A. (2017). Development of recombinant Yarrowia lipolytica producing virus-like particles of a fish nervous necrosis virus. J. Microbiol. 55, 655-664. doi: 10.1007/ s12275-017-7218-5

Ma, K., Bao, Q. W., Wu, Y., Chen, S. W., Zhao, S. X., Wu, H. Z., et al. (2020b). Evaluation of microalgae as Immunostimulants and recombinant vaccines for diseases prevention and control in aquaculture. Front. Bioeng. Biotechnol. 8:590431. doi: $10.3389 /$ fbioe.2020.590431 
Ma, J., Bruce, T. J., Jones, E. M., and Cain, K. D. (2019). A review of fish vaccine development strategies: conventional methods and modern biotechnological approaches. Microorganisms 7:18. doi: 10.3390/microorganisms7110569

Ma, F. S., Zhang, E. Q., Li, Q. M., Xu, Q. R., Ou, J. Q., Yin, H., et al. (2020a). A plant-produced recombinant fusion protein-based Newcastle disease subunit vaccine and rapid differential diagnosis platform. Vaccine 8:15. doi: 10.3390/ vaccines 8010122

Maliga, P., and Bock, R. (2011). Plastid biotechnology: food, fuel, and medicine for the 21st century. Plant Physiol. 155, 1501-1510. doi: 10.1104/pp.110.170969

Marsian, J., Hurdiss, D. L., Ranson, N. A., Ritala, A., Paley, R., Cano, I., et al. (2019). Plant-made nervous necrosis virus-like particles protect fish against disease. Front. Plant Sci. 10:880. doi: 10.3389/fpls.2019.00880

Molina, A., Hervas-Stubbs, S., Daniell, H., Mingo-Castel, A. M., and Veramendi, J. (2004). High-yield expression of a viral peptide animal vaccine in transgenic tobacco chloroplasts. Plant Biotechnol. J. 2, 141-153. doi: 10.1046/j.14677652.2004.00057.x

Molina, A., Veramendi, J., and Hervás-Stubbs, S. (2005). Induction of neutralizing antibodies by a tobacco chloroplast-derived vaccine based on a B cell epitope from canine parvovirus. Virology 342, 266-275. doi: 10.1016/j.virol.2005.08.009

Noad, R., and Roy, P. (2003). Virus-like particles as immunogens. Trends Microbiol. 11, 438-444. doi: 10.1016/S0966-842X(03)00208-7

Rosales-Mendoza, S., Nieto-Gomez, R., and Angulo, C. (2017). A perspective on the development of plant-made vaccines in the fight against Ebola virus. Front. Immunol. 8:252. doi: 10.3389/fimmu.2017.00252

Rosenthal, J. A., Chen, L., Baker, J. L., Putnam, D., and DeLisa, M. P. (2014). Pathogen-like particles: biomimetic vaccine carriers engineered at the nanoscale. Curr. Opin. Biotechnol. 28, 51-58. doi: 10.1016/j.copbio.2013.11.005

Roy, S., Tyagi, A., Tiwari, S., Singh, A., Sawant, S. V., Singh, P. K., et al. (2010). Rabies glycoprotein fused with B subunit of cholera toxin expressed in tobacco plants folds into biologically active pentameric protein. Protein Expr. Purif. 70, 184-190. doi: 10.1016/j.pep.2009.10.002

Ruf, S., Hermann, M., Berger, I. J., Carrer, H., and Bock, R. (2001). Stable genetic transformation of tomato plastids and expression of a foreign protein in fruit. Nat. Biotechnol. 19, 870-875. doi: 10.1038/nbt0901-870

Ruhlman, T., Ahangari, R., Devine, A., Samsam, M., and Daniell, H. (2007). Expression of cholera toxin B-proinsulin fusion protein in lettuce and tobacco chloroplasts - oral administration protects against development of insulitis in non-obese diabetic mice. Plant Biotechnol. J. 5, 495-510. doi: 10.1111/j. 1467-7652.2007.00259.x

Ruhlman, T., Verma, D., Samson, N., and Daniell, H. (2010). The role of heterologous chloroplast sequence elements in transgene integration and expression. Plant Physiol. 152, 2088-2104. doi: 10.1104/pp.109.152017

Rybicki, E. P. (2010). Plant-made vaccines for humans and animals. Plant Biotechnol. J. 8, 620-637. doi: 10.1111/j.1467-7652.2010.00507.x

Rybicki, E. P. (2014). Plant-based vaccines against viruses. Virol. J. 11:20. doi: 10.1186/s12985-014-0205-0

Shefat, S. (2018). Vaccines for use in finfish aquaculture. Acta. Scient. Pharmaceut. Sci. 2, 15-19.

Siriwattananon, K., Manopwisedjaroen, S., Kanjanasirirat, P., Purwono, P. B., Rattanapisit, K., Shanmugaraj, B., et al. (2021). Development of plant-produced recombinant ACE2-fc fusion protein as a potential therapeutic agent against SARS-CoV-2. Front. Plant Sci. 11:604663. doi: 10.3389/fpls.2020.604663

Sneeringer, S., Bowman, M., and Clancy, M. (2019). Economic Research Report 290026. United States: Department of Agriculture, Economic Research Service.

Specht, E., Miyake-Stoner, S., and Mayfield, S. (2010). Micro-algae come of age as a platform for recombinant protein production. Biotechnol. Lett. 32, 1373-1383. doi: 10.1007/s10529-010-0326-5

Streatfield, S. J. (2010). Approaches to achieve high-level heterologous protein production in plants. Plant Biotechnol. J. 5, 2-15. doi: 10.1111/j.14677652.2006.00216.x

$\mathrm{Su}, \mathrm{H}$. , and Su, J. G. (2018). Cyprinid viral diseases and vaccine development. Fish Shellfish Immunol. 83, 84-95. doi: 10.1016/j.fsi.2018.09.003

Su, H., van Eerde, A., Steen, H. S., Heldal, I., Haugslien, S., Ørpetveit, I., et al. (2021). Establishment of a piscine myocarditis virus (PMCV) challenge model and testing of a plant-produced subunit vaccine candidate against cardiomyopathy syndrome (CMS) in Atlantic salmon Salmo salar. Aquaculture 541:736806. doi: 10.1016/j.aquaculture.2021.736806

Svoboda, E. (2020). Research round-up: antimicrobial resistance. Nature 586, S58-S59. doi: 10.1038/d41586-020-02887-0
Tabatabaei, I., Dal Bosco, C., Bednarska, M., Ruf, S., Meurer, J., and Bock, R. (2019). A highly efficient sulfadiazine selection system for the generation of transgenic plants and algae. Plant Biotechnol. J. 17, 638-649. doi: 10.1111/pbi.13004

Tacket, C. O. (2009). Plant-based oral vaccines: results of human trials. Curr. Top. Microbiol. Immunol. 332, 103-117. doi: 10.1007/978-3-540-70868-1_6

Takeyama, N., Kiyono, H., and Yuki, Y. (2015). Plant-based vaccines for animals and humans: recent advances in technology and clinical trials. Therap. Adv. Vaccin. 3, 139-154. doi: 10.1177/2051013615613272

Tatsuhiko, A., Yoshikazu, Y., and Hiroshi, K. (2014). Challenges in mucosal vaccines for the control of infectious diseases. Int. Immunol. 26:517. doi: 10.1093/intimm/dxu063

Tuse, D., Nandi, S., McDonald, K. A., and Buyel, J. F. (2020). The emergency response capacity of plant-based biopharmaceutical manufacturing-what it is and what it could be. Front. Plant Sci. 11:594019. doi: 10.3389/fpls.2020.594019

Van Eck, J., and Keen, P. (2009). Continued expression of plant-made vaccines following long-term cryopreservation of antigen-expressing tobacco cell cultures. In Vitro Cell. Develop. Biology-Plant 45:750. doi: 10.1007/s11627-009-9231-9

van Eerde, A., Gottschamel, J., Bock, R., Hansen, K. E. A., Munang'andu, H. M., Daniell, H., et al. (2019). Production of tetravalent dengue virus envelope protein domain III based antigens in lettuce chloroplasts and immunologic analysis for future oral vaccine development. Plant Biotechnol. J. 17, 1408-1417. doi: 10.1111/pbi.13065

van Eerde, A., Varnai, A., Jameson, J. K., Paruch, L., Moen, A., Anonsen, J. H., et al. (2020). In-depth characterization of Trichoderma reesei cellobiohydrolase TrCel7A produced in Nicotiana benthamiana reveals limitations of cellulase production in plants by host-specific post-translational modifications. Plant Biotechnol. J. 18, 631-643. doi: 10.1111/pbi.13227

Verma, D., Moghimi, B., Loduca, P. A., Singh, H. D., Hoffman, B. E., Herzog, R. W., et al. (2010). Oral delivery of bioencapsulated coagulation factor IX prevents inhibitor formation and fatal anaphylaxis in hemophilia B mice. Proc. Natl. Acad. Sci. U. S. A. 107, 7101-7106. doi: 10.1073/pnas.0912181107

Vidal-Meireles, A., Neupert, J., Zsigmond, L., Rosado-Souza, L., Kovacs, L., Nagy, V., et al. (2017). Regulation of ascorbate biosynthesis in green algae has evolved to enable rapid stress-induced response via the VTC2 gene encoding GDP-(L)-galactose phosphorylase. New Phytol. 214, 668-681. doi: $10.1111 /$ nph. 14425

Visuthismajarn, P., Vitayavirasuk, B., Leeraphante, N., and Kietpawpan, M. (2005). Ecological risk assessment of abandoned shrimp ponds in southern Thailand. Environ. Monit. Assess. 104, 409-418. doi: 10.1007/s10661-005-1681-x

Wu, Y., Zhao, D., Song, L., and Xu, W. (2009). Heterologous expression of synthetic chicken IFN- $\gamma$ in transgenic tobacco plants. Biologia 64, 1115-1122. doi: 10.2478/s11756-009-0203-7

Yang, Z. Q., Liu, Q. Q., Pan, Z. M., Yu, H. X., and Jiao, X. A. (2007). Expression of the fusion glycoprotein of Newcastle disease virus in transgenic rice and its immunogenicity in mice. Vaccine 25, 591-598. doi: 10.1016/j.vaccine.2006.08.016

Yao, Y. Y., Yang, Y. L., Gao, C. C., Zhang, F. L., Xia, R., Li, D., et al. (2020). Surface display system for probiotics and its application in aquaculture. Rev. Aquac. 12, 2333-2350. doi: 10.1111/raq.12437

Yusibov, V., Streatfield, S. J., and Kushnir, N. (2011). Clinical development of plant-produced recombinant pharmaceuticals vaccines, antibodies and beyond Hum. Vaccin. 7, 313-321. doi: 10.4161/hv.7.3.14207

Conflict of Interest: The authors declare that the research was conducted in the absence of any commercial or financial relationships that could be construed as a potential conflict of interest.

Publisher's Note: All claims expressed in this article are solely those of the authors and do not necessarily represent those of their affiliated organizations, or those of the publisher, the editors and the reviewers. Any product that may be evaluated in this article, or claim that may be made by its manufacturer, is not guaranteed or endorsed by the publisher.

Copyright (c) 2021 Su, Yakovlev, van Eerde, Su and Clarke. This is an open-access article distributed under the terms of the Creative Commons Attribution License (CC BY). The use, distribution or reproduction in other forums is permitted, provided the original author(s) and the copyright owner(s) are credited and that the original publication in this journal is cited, in accordance with accepted academic practice. No use, distribution or reproduction is permitted which does not comply with these terms. 